\title{
TYPE LOCALITIES OF TWO SATYRID BUTTERFLIES
}

NORBERT G. KONDLA, Box 762, McBride, BC. VOJ 2E0

The purpose of this note is to clarify and restrict the type localities of two butterfly taxa: Oeneis nahanni (Nahanni Arctic) which is placed as a subspecies of $O$. Uhleri in contemporary literature and Coenonympha mackenziei (Mackenzies' Ringlet) which is variously placed as a subspecies of $C$. ochraces or $C$. tullia in contemporary literature.

Dyar loosely gave the type locality for O. nahanni as "Nahanni Mtns., Mackenzie." ${ }^{3}$ This vague and largely useless type locality description has been perpetuated in the literature despite the fact that the collector of the type material gave a very accurate description of the type locality. ${ }^{1}$

Cary reported collecting the type pair on Mount Tha-on-tha, Nahanni Mtns., Mackenzie. He also reported that this mountain is "an isolated peak not more than 5 miles from the confluence of the North Nahanni and Mackenzie Rivers." Further, he reported that the literal translation of the Slave Indian "Tha-on-tha" is "by itself." National Topographic System map sheet $95 \mathrm{~J}$ shows that this mountain is now called Lone Mountain and is located at about $62^{\circ} 11^{\prime} \mathrm{N}$, $123^{\circ} 16^{\prime} \mathrm{W}$.

Cary also referred to the Nahanni Mtns. as being "an eastern spur of the Rockies." It should be noted that Lone Mountain is in fact the northern terminous of the Nahanni Range which is part of the Mackenzie
Mountains.

The type locality of Oeneis uhleri nahanni, using modern geographic names, is therefore restricted to Lone Mountain, Nahanni Range, Mackenzie Mountains, Northwest Territories.

Davenport gave the type locality of C. mackenziei as "Nyarling River, Mackenzie Dist." Again, this is not a useful type locality because the Nyarling River is more than $100 \mathrm{~km}$ long.

The type material was collected on 4 and 11 July 1926 by J. Russell. According to Raup, John Russell was a Dominion Land Surveyor engaged in the first survey of this region in 1926. ${ }^{4}$ Russell also collected plants that are reported by Raup. These plant collections include many grassland species from the "junction of the Nyarling and Little Buffalo Rivers." Since a perpetual calendar shows that the type material was collected on Sundays, it is reasonable to postulate that Russell collected the specimens while engaged in natural history studies in the vicinity of the survey party camp on his days of rest.

I was able to confirm this through copies of Russell's field notes kindly provided by G.E. Olsen of Energy, Mines and Resources Canada. The field notes confirm that Russell was camped "on the edge of a wide grass 
meadow" beside the Nyarling River about $0.8 \mathrm{~km}$ from its confluence with the Little Buffalo River from 4-11 July inclusive. Further, the field notes confirm that Russell did not engage in survey work on the dates that the type specimens were collected.

The type locality of Coenonympha ochracea mackenziei is therefore restricted to the Nyarling River, $0.8 \mathrm{~km}$ from its confluence with the Little Buffalo River, Northwest Territories $\left(60^{\circ} 40^{\prime} \mathrm{N}, 113^{\circ} 25^{\prime} \mathrm{W}\right)$.
1. CARY, M. 1906. On the diurnal lepidoptera of the Athabasca and Mackenzie Region, British America. Proceedings of the United States National Museum 31:425-457.

2. DAVENPORT, D. 1936. A new American Coenonympha. Canadian Entomologist 68:79.

3. DYAR, H.G. 1904. Two new forms of Oeneis. Proceedings of the Entomological Society of Washington 6:142.

4. RAUP, H.M. 1935. Botanical investigations in Wood Buffalo Park. National Museum of Canada Bulletin 74. $74 p p$.

Consider this familiar paradox of biological diversity: almost all the species that ever lived are extinct, and yet more are alive today than at any time in the past. The solution of the paradox is simple. The life and death of species have been spread across more than three billion years. If most species last an average of, say, a million years, then it follows that most have expired across that vast stretch of geologic time, in the same sense that almost all the people who ever lived during the past 10,000 years are dead though the human population is larger than it has ever been. The turnover would have been even greater if the grand pattern were dynastic, with one species giving rise to many species, most or all of which yielded to later ascendant groups. Wilson, E.O. 1992. The diversity of life. W.W. Norton and Company, New York. 424 pp. 